\title{
UNACCOMPANIED MINORS AND YOUTH OF REFUGEE BACKGROUND IN THE CONTEXT OF SWEDISH SCHOOL REFORMS OF 2018. INCLUSIVE EDUCATION FOR MIGRANTS' INTEGRATION
}

\author{
Monika Banaś \\ Jagiellonian University, Krakow (POLAND)
}

\begin{abstract}
This article deals with issues connected with secondary education reforms introduced in Sweden in July 2018. However, it is important to analyse this regarding another significant phenomenon, namely immigration. Following the outbreak of the so-called migration crisis of 2015 , Sweden received a number of asylum applications which was greater than any up to that point, including 35,369 filed by unaccompanied minors. As children, such people were placed under special protection. They were also ensured access to suitable education considering their particular needs. With the passage of time and changing international circumstances, a number of the countries or regions from which these minors had come were, in the view of the Swedish Migration Agency, deemed to be safe. This meant that young refugees were now liable to lose their refugee status and could be returned to their countries of origin. The reform of secondary education, a move which has aroused much controversy, is meant de facto to create opportunities for such people to extend their stay in Sweden. This, however, is subject to certain conditions, such as the choice of one's educational pathway being in close correlation with the labour market (vocational education). Current secondary education reforms may be read as a further modified element which is part of a significantly broader structure determined by the framework of Sweden's integration policies.
\end{abstract}

Keywords: unaccompanied minors, education, integration, Sweden.

\section{INTRODUCTION}

Sweden's new law on secondary education came into force on 1 July 2018. It concerns migrant youth (16-19 years old) who came to Sweden as refugees but subsequently lost their eligibility for asylum as a result of a changing international context based on, for instance, the end of armed conflict in their country of origin or threats to life or health being no longer present there. The law introduced inter alia by the Swedish Migration Agency (Swedish: Migrationsverket) precludes these individuals from further extending their stay based on claims for asylum. Instead, such young adults are invited to leave Sweden and go back to their home countries.

The reform, along with its procedures and compulsory practices, drew strong criticism and disapproval mainly from school staff, namely teachers and educators directly involved in working with migrants and refugees. In addition, one of the bodies representing refugees, that is the Unaccompanied Minors Association (Ensamkommandes Förbund) expressed its confusion about a new law concerning junior high schools (Gymnasielagen). Controversies arise especially concerning young people who arrived in Sweden as children but are now 16 years and older. However, the new law opens up the possibility for young adults to prolong their stay in Sweden on condition that they continue their education, especially in areas associated with vocational training.

The new law has imposed curriculum modification on secondary schools taking into account both the needs of the Swedish labour market and the needs of young migrants/refugees. In this context, psycho-cultural aspects are especially relevant considering two major facts: 1) migrant youth growing up in at least two cultural settings, namely the culture of their country/region of origin and Swedish culture; and 2) the traumatic experiences of refugee minors hampering their integration with the host society.

The proposed solutions resulting from the reform of secondary education have both their supporters and opponents, the latter expressing doubts about the real effectiveness of the reforms, an aspect which is developed in the following sections of this article. 


\section{METHODOLOGY}

The issues presented in the article are a result of a deeper analysis from the perspective of cultural studies and political science and based on the following pillars: 1) a desk research analysis concerning the reform of secondary education available on the Swedish education ministry website; 2 ) expert commentary, mainly from teachers, practitioners and politicians with an interest in such matters; and 3) refugees' and migrants' representative bodies, such as the Unaccompanied Minors Association. The above-mentioned sources of information have been supplemented by the data gained during my field research I conducted in Sweden in 2019. While visiting selected cities and municipalities with a high percentage of migrants (immigrants and refugees) I had the possibility to conduct interviews with individuals actively engaged in the implementation of the integration policies introduced in Sweden after 2015. A relevant methodological input in my study comes from the visual anthropology approach, which allowed to analyse the phenomenon in its real context on the spot regarding infrastructure, coordination and management of the migrants' reception in Sweden. Both approaches, the theoretical and practical, complementing each other provide a more complete picture of the discussed problem. At the same time, they point to the fact that migrant integration policies to be effective need to rely on 1) extraordinarily well-conceptualized and coherent visions, 2) well performed and executed programs and actions, and 3) a harmonic cooperation between the host society and the newcomers.

\section{UNACCOMPANIED MINORS IN THE CONTEXT OF MIGRATION AFTER 2015}

Sweden, as a highly developed country, is one of the most frequently chosen destinations by those seeking asylum. Indeed, a high percentage of the asylum applications filed each year concern Sweden. In 2015, this amounted to 162,877 applications which constituted a significant proportion of all applications $(1,325,000)$ recorded in the European Union (EU), as well as those European countries remaining outside its structures [1]. Among the asylum applications filed in Sweden in the above-mentioned year, 35,369 came from unaccompanied minors. Two years later, in 2017, the number of asylum applications filed in Sweden had fallen. In the case of the above-described group of minors, this amounted to 1,336 applications [2]. It is worth emphasising that the significant drop in all asylum applications at the turn of 2016/2017 was not so much a result of changes in the circumstances regarding the countries sending refugees but more due to the introduction of internal border controls between Denmark and Sweden, as well as an agreement being reached between the EU and Turkey on the issue of the readmission of refugees [3].

Refugee minors seeking protection in Sweden mainly came from five countries, namely Afghanistan, Somalia, Syria, Eritrea and Iraq. Close to $80 \%$ of them were children and young men which correlates with similar proportions in the case of adult migration [4]. This is a consequence of a strictly cultural factor, one formatting intra-societal relations determined by male domination and supremacy.

Among 7,480 asylum applications filed by unaccompanied minors in 2017, the Swedish authorities positively assessed most of them, namely 5,429 , which constituted $79 \%$ of all applications filed by minors [5]. One must stress, however, that during the period of 2015-2018, the number of positively assessed applications fell. This was a result of tightened-up regulations determining the granting of asylum and the awarding of refugee status. The relatively generous granting of asylum, in comparison with other countries, by the Swedish government to those not necessarily from regions affected by armed conflict, resulted in increasing criticism in the forum of public opinion. This was effectively taken advantage of by anti-immigrant parties, particularly the Sweden Democrats (Sverige Demokraterna) demanding changes to the country's immigration policies [6]. In fact, during the first two decades of the $20^{\text {th }}$ century (2000-2019), the regulations determining Sweden's policies on immigration and integration have undergone gradual modification, moving from a liberal to a more conservative position, i.e. comprising more requirements regarding immigrants themselves, including refugees [7]. Among the tightened-up requirements can be found such solutions as: compulsory learning of the Swedish language and the realities of Swedish politics and society (socio-political and cultural knowledge), an accelerated process of incorporation into the labour market by taking up vocational and further education courses, the lowering of adaptation allowances (including unemployment benefit), as well as shortening their availability. Such solutions are aimed at activating immigrants and, importantly, speeding up their incorporation into the Swedish labour market. This is crucial insofar as the statistical data on immigrants, including refugees, shows that they still constitute a less-active group professionally in comparison with native Swedes. This situation has remained the same for many years despite the running of special integration programmes. For example, in 2018 the 
professional activity rate of immigrants aged 20-64 years comprised $70.1 \%$, while among native Swedes this was $86.5 \%$ [8]. Such a high disproportion has a detrimental effect on the integration process necessary for building social cohesion which, in turn, is one of the basic conditions for the building and functioning of a country's prosperity.

The cause of lower professional activity among immigrants should be sought in the origin of their migration. Although in the period of 1950-1980 mainly economic immigrants came to Sweden, this was followed by refugees after 1990. In the case of the latter, their integration into society proceeded at a significantly slower pace. This was caused by the frequently dreadful experiences of the new arrivals, burdened with the trauma of war, persecution, torture or oppression. For this reason, the range of integration programmes aimed at immigrants included courses featuring therapy sessions, along with vocational, educational and further education courses. This is especially important in the case of children and young people. With them in mind, special educational pathways were created aimed at, on the one hand, delivering the knowledge essential to function in a highly developed Western society, while on the other hand, working through the trauma of tragic wartime experiences they had brought with them from their country or region of origin [9].

\subsection{Minors and Swedish law}

This section covers the issue of a recently revived discussion which has arisen not only in Sweden but in other Nordic countries. This concerns the legal aspects or personal details, minors in this case, which determine whether they received refugee status and thereby the right to stay, albeit for a limited period of time. Time limits are the result of a change in Sweden's asylum law of 2016 which allow the asylum seeker to be returned to their country/region of origin, only if circumstances allow. Although in some cases this is possible (e.g. Afghanistan, Ethiopia, Kosovo), in others it is not (e.g. Yemen, NorthWest Pakistan, South Sudan). The tightening-up of the asylum law has resulted from several facts, among which is the overburdening of the Swedish system of receiving refugees, which has proved to be less capable in the face of a significant increase in the number of those in need. Another reason is the insufficient accuracy regarding the identification of those entitled to receive asylum. In large groups of refugees, there are people in possession of no documents whatsoever. As has been shown in practice, they included individuals who should not have been awarded refugee status. Therefore, they had come from regions neither affected by conflict nor the threat of conflict [10]. The decision of the Swedish authorities taken in the face of insufficient data initiated the development of a nationwide discussion on the subject of reviewing Swedish migration and asylum laws, as well as a review of the procedures for verifying whether one was a minor. As it turned out, migrants above the age of 18 years were to be found among those declaring themselves to be minors and stating that they had no identification documents whatsoever [11]. As the number of cases arousing suspicion was not low, it was decided to introduce special medical examinations aimed at assessing the age of applicants. This was entrusted to the National Board of Forensic Medicine (Rättsmedicinalverket) which has been using X-rays of teeth or knees as verification material since 2017. In the above-mentioned year, this procedure covered almost $65 \%$ of all those submitting themselves as minors and applying for asylum. However, as this practice does not provide an unambiguous result, a final decision based on all of the documentation, an individual interview, as well as - insofar as possible - information secured from the refugee's country of origin, is made by the Swedish Migration Agency (Migrationsverket). Since the beginning of the migration crisis (2015) up to today (2019), close to $80 \%$ of cases filed as the applications of minors have been deemed by the Migration Agency to be those of young adults [12]. This is important insofar as different protective mechanisms are used for these two different groups, with those for children being significantly broader and more generous. For instance, every child living in Sweden has the same right of access to housing, health care and education. An additional particular right is that concerning so-called family re-union, and more precisely, the speeding up and reduction of these procedures in the case of underage refugees. After 2015, this practice has been significantly cut back on the strength of a temporary law (den tillfälliga lagen) introduced as a remedy for the problems resulting from the influx of too high numbers of migrants (immigrants, including refugees) to Sweden.

As the main decision-maker in issuing acceptance or rejection of asylum applications, the Migration Agency works closely with local authorities as they are directly responsible for the receiving of migrants. Asylum seekers are directed to local authorities according to the principles of proportional distribution, meaning those which do not cause financial burden for the budget of an administrative unit, resulting in hyper-debt. The very same redistributive mechanism is used in the case of children and young people. However, it should be emphasised that this kind of distribution bears its own consequences correlating with the level of wealth of particular municipalities. While some are 
wealthier, others are more indebted, which impacts on the quality of social welfare guaranteed. However, each local authority accepting a refugee minor is entitled to apply for additional funding $(500,000$ SEK annually). This is crucial insofar as, in the case of children and young people, it allows for the organisation of better services, such as infrastructural, medical, psychological and educational services.

\subsubsection{Gymnasielagen}

The consequences of the 2015 migration crisis also left their mark in the field of education or, more precisely, the laws regulating it. The law passed by the Swedish parliament in 2017 entitled Gymnasielagen 2017 (Junior High School Law or Second Level Education Law 2017), concerns secondary education. It addresses minors who, during the verification process by the Swedish Migration Agency, have been negatively assessed, thereby meaning they are to be returned to their country of origin. In the case of minors this is not possible, as long as care in their home country cannot be assured. Being returned to one's country of origin only becomes possible once an individual has reached the age of majority. However, here also an exception has been created by the Gymnasielagen: individuals assigned for deportation from Sweden who are continuing or have commenced studying at the level of secondary education may apply to have their negative assessment by the Migration Agency lifted [13]. The above-mentioned 2017 law encountered strident criticism from various circles, including legal circles stressing the ambiguity of the law, thereby allowing it to be interpreted in a broad and varied manner [14], [15]. For this reason, one year later on 7 June 2018, the Swedish Parliament passed a subsequent law concerning the issues raised, entitled Gymnasielagen 2018 [16]. Within its remit, additional circumstances were defined opening up a way for young asylum seekers to apply for a review of their rejection by the Migration Agency. Apart from the above-mentioned basic condition - the continuation of education, including vocational training additional conditions were also defined, namely: 1) that one's application for asylum had not been filed later than 24 November 2015 and that the person concerned had, at the same time, been registered with the Migration Agency as an unaccompanied minor; 2) the decision of the Migration Agency giving rise to an appeal had been delivered later than 15 months since the application for asylum; the person concerned was over 18 years of age; and 4) they had not committed any crime. The above-outlined conditions entitled the applicant to receive a temporary right of residency for a period of 13 months with the possibility of a further conditional extension as long as progress in one's education or vocational training had been observed. If the person concerned showed promise in being able to maintain themselves and had taken up permanent employment within six months of finishing their education, they could apply for permanent residency.

Unfortunately, this version of the law, which came into force in September 2018, was also criticised in educational and legal circles and those involved in helping refugees [17], [18], [19]. Once again criticism concerned the lack of precision in the law related with its freedom of interpretation and unnecessary complication of matters. Above all, the National Teachers' Association (Lärarnas riksförbund) stressed that the law had mandated a designated section of teachers (examiners) with making decisions or a given educational pathway and the institutions offering it, which may be covered by the Gymnasielagen. Lawyers pointed out the insufficient care legislators had taken when one looked at the content of the law, as well as the lack of compatibility with already existing laws. In turn, non-governmental organisations helping refugees have discerned a lack of justification for the time framework laid out in the law.

Critical views against the very concept of the Gymnasielagen were voiced by politicians, mainly on the right (the Moderater and Sverigedemokrater parties). In their opinion the law created additional problems for local authorities concerning their responsibility to ensure housing for refugees. At this point, it must be emphasised that a housing crisis lasting many years had affected the entire country, along with the wealthier district councils to which just a number of refugees were being sent. In the above-described situation, less-wealthy councils were forced to take on further challenges bearing financial consequences in the form of growing debt.

A further argument against the law addressed by right-of-centre politicians is the downplaying by legislators of the fact that procedures and mechanisms of verifying the identity of applicants have proved insufficient. Opponents of the law perceive in its text an open door into Sweden for people emerging from criminal environments or those threatened by terrorist indoctrination.

Critics of the governing law also include the Swedish Association of Local Authorities and Regions (Sveriges kommuner och regioner, SKR). It has pointed out the law's lack of effectiveness and inappropriateness to actual needs. The most problematic issue indicated by officials directly involved 
with implementing the law at the basic (local authority) and middle (region) are the insufficient financial resources facilitating the preparation of effective educational programs, the generally low competence of the applicants for taking up studies at secondary level (from which arises a need to prepare introductory courses), the frequent appearance of problems of psychological nature among the applicants which in turn forces officials to organise proper psychological care, as well as what is known as a parallel society on a national scale, forming from those who have not integrated with Swedish society [20].

\subsection{Education and integration}

With several decades of experience of having been a country of immigration, contemporary Sweden has developed educational programmes offered to migrants (immigrants, including refugees) which are aimed at facilitating and speeding up their integration into the host society. Integration in the social, cultural, political and, above all, economic fields is an essential condition for the effective functioning of a country and society, both at a regional and global level. According to the Migrant Integration Policy Index (MIPEX), Sweden occupies first place among 38 countries ranked when it comes to creating the best conditions for the integration of migrants [21]. Unfortunately, in practice quite a different picture is painted. Becoming ever clearer are, among other things, the divisions and disproportions occurring in housing (ghettoisation), employment levels (higher for native Swedes and lower for immigrants), socio-political engagement or educational levels [22]. Indeed, the last of these seems to be particularly important in light of Swedish immigration policies after 2015. This is why special educational pathways, both secondary and vocational, have been created aimed at migrants.

The first of these, opening up the entire process, is validation and assessment of the theoretical and practical competence of the migrant. This stage is coordinated by the Swedish Council for Higher Education (Universitet och Högskolerådet, UHR) in cooperation with the Swedish Public Employment Service (Arbetsförmedlingen). This is aimed at standardising actions directed at the future needs of the labour market so that future workers will be able to find employment compatible with the real needs of the market.

The next educational-vocational pathways subsidised by the government are: 1) vocational training (etableringsjobb); 2) initial employment (introduktionsjobb); 3) new employment (nystartsjobb); additional work (extratjänst), as well as fast track (snabbspår). It is worth emphasising that although such pathways or programmes are aimed above all at migrants, they may also be availed of by native Swedes who remain long-term unemployed.

Particular focus should be placed on etableringsjobb. This is a programme which, in contrast to the others, is developed together by the government and representatives of Swedish employers. An agreement between these parties, which came into force in late 2019, is aimed, in its pilot phase, at covering at least 10,000 individuals. Employment is meant to result in their being long-term professionally active while simultaneously strengthening the private business sector where the demand for labour, depending on the area, remains relatively high (such as construction, forestry, catering, hotels, healthcare, care of the elderly).

Introduktionsjobb is a programme facilitating the gaining of vocational work experience and supplementing theoretical training. Those taking up this kind of employment may study as part of its remit, with this time being counted towards their period of employment. Such studies are meant to constitute the supplementation of work experience and are, therefore, meant to be compatible with one's target job. Although they are subsidised by the government up to a level of $80 \%$ of the costs, this may not exceed 20,000 SEK per month.

The next form of pathway aimed at supporting permanent employment is the nystartjobb programme. Co-financed to a significant degree by the government ( $50 \%$ of the costs, including salary costs), it is aimed at encouraging employers to offer immigrants the opportunity of gaining work experience, verification of practical skills and, above all, the opportunity to secure employment leading to financial independence. In the case of immigrants, this kind of employment must commence no later than 36 months from the moment a residency permit was granted.

Extratjänst is a particular type of subsidised programs which concerns employment only in state-run enterprises or institutions providing not-for-profit services. The entity receiving the employee in line with this kind of employment receives financial support of up to 20,000 SEK for a monthly salary as part of a full time employment contract. 
The last of the pathways to be discussed here is snabbsparr, which is addressed exclusively to migrants who already possess relevant competence in taking up employment in a sector with a great shortage of labour. This programme is comprised of three stages, namely: the validation of one's skills on the basis of documents, work practice aimed at checking one's actual skills, as well as courses supplementing and developing competences already possessed. It should be stressed once again that this type of educational-vocational pathway, developed by three parties: employers, trade unions and the public employment service, concerns sectors with a significant and sometimes even dramatic labour shortage.

\section{CONCLUSIONS}

The issue of modifying the law concerning second-level education presented in this article has two actual aims. Firstly, the possibility of young migrants staying on in Sweden to whom the state has denied asylum and, secondly, incorporating them into the Swedish labour market, above all into sectors with a great labour force deficit. These sectors include, among others, construction, forestry, catering, hotels, healthcare (especially palliative care) or care of the elderly. An ageing Swedish society, similar to many other highly developed societies, has been forced to use foreign labour. The accelerated integration of newly arrived individuals, regular migrants and refugees, correlates with their age. It is easier to integrate adolescents than adults into a new country. Although this does not concern every case without exception, the experience of Swedish society has provided examples to prove this rule [23].

The educational reforms of 2017 and 2018, defined by the common term Gymnasielagen have their strong supporters and opponents. Opinions are divided. This especially concerns the issue whether changing the law in a fundamental way will indeed result in an increase in the number of young people studying who had arrived in Sweden as unaccompanied minors, and who Sweden eventually decided to turn down for asylum at a later stage.

\section{ACKNOWLEDGEMENTS}

The findings of the paper are based on a research project financed by the National Science Centre, Poland, program OPUS 12, grant nr. 2016/23/B/HS5/00140.

\section{REFERENCES}

[1] Asylum seekers to Sweden 2000 - 2018, Sweden and Migration, Retrieved fromhttps://sweden.se/migration/\#2015. also https://www.pewresearch.org/global/2016/08/02/number-of-refugees-to-europe-surges-to-record1-3-million-in-2015/.

[2] Migrationsinfo, 2019. Retrieved from https://www.migrationsinfo.se/migration/sverige/asylsokandei-sverige/ensamkommande-barn/\#fnref-140-8.

[3] Euractive, 2016, Retrieved from https://www.euractiv.com/section/justice-homeaffairs/opinion/safeguards-needed-for-eu-turkey-migration-deal/. also https://www.euractiv.pl/section/polityka-zagraniczna/news/jest-porozumienie-z-turcja/.

[4] Migratiotionsverket, 2017, Inskrivna personer i Migrationsverkets mottagningsystem, pp. 17 - 23. Retrieved from https://www.migrationsverket.se/Om-Migrationsverket/Statistik/Asyl.html.

[5] Migrationsinfo, 2019. Retrieved from https://www.migrationsinfo.se/migration/sverige/asylsokandei-sverige/ensamkommande-barn/\#fnref-140-8.

[6] https://www.pewresearch.org/global/2016/08/02/number-of-refugees-to-europe-surges-to-record1-3-million-in-2015/.

[7] M. Banaś, "Anti - Immigrant Sentiment, Actions, and Policies in Europe. The Case of Three Scandinavian Countries" in Anti - Immigrant Sentiment, Actions, and Policies (ed. Monica Verea), pp.405-426, UNAM, CISAN, Mexico, 2012. 
[8] CSB, 2019, Arbetskraftsundersökningarna 2018, Grundtabeller årsmedeltal 2018, Tabel 1, Retrieved from https://www.scb.se/hitta-statistik/statistik-efter-

amne/arbetsmarknad/arbetskraftsundersokningar/arbetskraftsundersokningarna-aku/pong/tabelloch-diagram/icke-sasongrensade-data/grundtabeller-aku-1574-ar-ar/.

[9] Statens Beredning för Medicinsk och Social Utvärdering, Raport Psykologisk, psykosocial och farmakologisk behandling vid posttraumatiskt stressyndrom (PTSD) hos barn och unga, 2019. Retrieved from https://www.sbu.se/sv/publikationer/sbu-kommentar/psykologisk-psykosocial-ochfarmakologisk-behandling-vid-posttraumatiskt-stressyndrom-ptsd-hos-barn-ochunga/?pub=39527.

[10] UNHCR, The UN Refugee Agency, "Entry, admission and reception / False documents", $6^{\text {th }}$ January 2020. Retrieved from https://www.refworld.org/topic,50ffbce53a,50ffbce54c,,0,,,CMR.html.

[11] SVT Nyheter, "Ny statistik visar: Minst 80 procent av undersökta asylsökande över 18 år", $2^{\text {nd }}$ August 2017. Retrieved from https://www.svt.se/nyheter/inrikes/ny-statistik-visar-minst-80-procentav-undersokta-asylsokande-over-18-ar.Sveriges Radio,"Migrationsverket varnar för nya svåra åldersbedömningar", $12^{\text {th }}$ January2017. Retrieved from https://sverigesradio.se/sida/artikel.aspx?programid=83\&artikel=6607037.

[12] https://www.migrationsinfo.se/migration/sverige/asylsokande-i-sverige/ensamkommandebarn/\#fnref-140-8.

[13] Sveriges Riksdag, "Lag (2017:353) om uppehållstillstånd för studerande på gymnasial nivå", Stockholm 2017. Retrieved from https://www.riksdagen.se/sv/dokument-lagar/dokument/svenskforfattningssamling/lag-2017353-om-uppehallstillstand-for_sfs-2017-353.

[14] Regeringen, Kammarrätten i Stockholm, Remissyttrande: Utkast till lagrådsremiss. Ny möjlighet till uppehållstillstånd, Stockhom $20^{\text {th }}$ February2018.

[15] "Yttrande om uppehållstillstånd för gymnasiestudier". Retrieved from https://www.farr.se/sv/omfarr/remissvar/1394-yttrande-om-uppehallstillstand-foer-gymnasiestudier, FARR Flyktinggruppernas riksråd.

[16] Sveriges Riksdag, "Extra ändringsbudget för 2018 - Ny möjlighet till uppehållstillstånd Finansutskottets betänkande 2017/18:FiU49", $7^{\text {th }}$ July 2018. Retrieved from https://www.riksdagen.se/sv/dokument-lagar/arende/betankande/extra-andringsbudget-for-2018--ny-mojlighet-till_H501FiU49.

[17] "Remissyttrande 002 från Kammarrätten i Stockholm 2018-02-20". Retrieved from https://www.regeringen.se/remisser/2018/01/remiss-av-utkastet-till-lagradsremiss-ny-mojlighet-tilluppehallstillstand/.

[18] "Remissyttrande 064 Lärarnas Riksförbund". Retrieved from https://www.regeringen.se/remisser/2018/01/remiss-av-utkastet-till-lagradsremiss-ny-mojlighet-tilluppehallstillstand/.

[19] "Remissyttrande 060 från Flyktinggruppernas Riksråd FARR". Retrieved from https://www.regeringen.se/remisser/2018/01/remiss-av-utkastet-till-lagradsremiss-ny-mojlighet-tilluppehallstillstand/.

[20] A. Knape, SKR (SKL), "En översyn av gymnasielagen kan inte vänta”, $17^{\text {th }}$ October 2019. Retrieved fromhttps://www.dagenssamhalle.se/debatt/skl-en-oversyn-av-gymnasielagen-kan-intevanta-29712.

[21] MIPEX, Migrant Integration Policy Index, Sweden 2015. Retrieved from http://www.mipex.eu/sweden.

[22] I.G. Schermer, "Utbildningsnivå - utrikes födda", $19^{\text {th }}$ November 2019. Retrieved from https://www.ekonomifakta.se/fakta/arbetsmarknad/integration/utbildningsniva/.

[23] M. Banaś, Swedish integration policy towards immigrants (Szwedzka polityka integracyjna wobec imigrantów), Kraków: Jagiellonian University Press, 2010. 